\title{
A Review of Heat Therapy in African Traditional Medicine
}

\author{
Nwokeke Chinyere Celine, Igwillo Ugochukwu Clifford* \\ Nigeria Natural Medicine Development Agency, Lagos, Nigeria \\ Email address: \\ Chinyerem555@gmail.com (N. C. Celine), ugoigwillo@yahoo.com (I. U. Clifford) \\ ${ }^{*}$ Corresponding author
}

\section{To cite this article:}

Nwokeke Chinyere Celine, Igwillo Ugochukwu Clifford. A Review of Heat Therapy in African Traditional Medicine. Journal of Health and Environmental Research. Vol. 6, No. 3, 2020, pp. 87-92. doi: 10.11648/j.jher.20200603.16

Received: July 22, 2020; Accepted: August 3, 2020; Published: August 20, 2020

\begin{abstract}
Heat therapy - also known as thermotherapy or thermal therapy - is the transfer of heat or thermal energy in and out of the human body especially at the joints, using towels, ice packs, wax, hot/warm water, steam, etc within a given temperature range. The objective is the expansion of blood capillaries and increased blood flow to the affected area for healing. The principle is the application of the heat or cold to change the cutaneous, intraarticular or core temperature of soft tissues to improve symptoms of certain conditions. Categories of heat therapy include: diathermia $\left(<41^{\circ} \mathrm{C}\right)$, hyperthermia $\left(41^{\circ} \mathrm{C}-45^{\circ} \mathrm{C}\right)$, and thermal ablation $\left(>45^{\circ} \mathrm{C}\right)$. Heat therapy is classified on the bases of contact of heat, mode of transfer, type of heat, penetration of heat, and use of heat. Examples include: steam inhalation, hot fomentations, hot foot bath, Seitz bath (hip bath and half-bath), hot and cold contrast bath, and sun therapy. Heat therapy has several benefits in African traditional medicine and has also been used extensively for treating various diseases including: sickle cell disease, primary dysmenorrhea, skeletomuscular pain, trauma, inflammatory and degenerative rheumatic diseases, osteoarthritis, acute and non-specific chronic low back pain, fibromyalgia, cutaneous leishmaniasis, tumours, musculoskeletal injuries, diabetic kidney disease, etc.
\end{abstract}

Keywords: Heat Therapy, Thermotherapy, Diathermia, Hyperthermia, Thermal Ablation, African Traditional Medicine

\section{Introduction}

The application of thermal agents such as heat or cold is popular in clinical and rehabilitative settings. Altering tissue temperature can have a range of therapeutic effects through changes in metabolism, nerve transmission, hemodynamics, and mechanical properties [1]. Heat therapy, also known as thermotherapy is the use of heat in the treatment of pain and other similar health conditions. Heat therapy is the application of heat to the body resulting in increased tissue temperature $[2,3]$. Thermotherapy involves applying heat or cold to joints and can be done with packs, towels, wax, etc. It has also been defined as the therapeutic application and transfer of thermal energy into or out of the human body resulting in increased tissue temperature [4-6]. "Thermo" refers to heat that changes the body temperature therapeutically to produce a hemodynamic effect. Heat therapy is an old but effective method of treatment of several diseases and ailments, especially musculoskeletal injuries and pains. Heat works by improving circulation and relaxing muscles; while cold numbs the pain, decrease swelling, constrict blood vessels and block nerve impulses to the joint [7]. Thermal therapy is applied in practice and by patients themselves as a self-management strategy [8]. Heat increases circulation in the human body, and helps to move nutrients to the joints and muscles. Generally, heat therapy is applied to decrease joint stiffness, reduce pain and inflammation, and relieve muscle spasms. Radiant heat therapy is among the various forms of medicines and therapies that constitute elements of African traditional medicine. Heat is also applied in fire therapy which is one the modalities of treatment in naturopathy system of medicine $[9,10]$. African traditional medicine men have been reported to be knowledgeable in application of water, heat and sun therapies [11].

\section{Brief History and Objective of Heat Therapy}

The use of thermal energy for therapeutic purposes dates back thousands of years. In the splendor of the Roman Empire, thermal baths constituted a habit, often with complete facilities for the treatment of diseases involving the 
use of humid and dry heat in local or general applications [12, 13]. The first documented use of heat therapy dates back to Hippocrates $(460-370 \mathrm{BC})$ who believed that if he had the power to produce fever, then he could cure all diseases. The practice also dates back to 500 B. C. when Egyptian physicians applied specific rules for sun and heat therapies. Native Americans used hot vapor baths to treat fevers, and to heal arthritis, neuritis, and rheumatism. Some decades ago, the aged in African communities used to sleep with fire place around or under their beds. This is because the heat from the fire provided warmth for the body, stimulated blood circulation and relieved pains. In local African setting, heat from fire is used extensively in the treatment of various ailments and diseases. Family members usually surround a lit fire place in order to keep warm especially during harmattan and early in the morning.

The primary objective of heat therapy is the expansion of blood capillaries, increased blood flow to the affected area that provides nutrients and oxygen for better healing. The principle of the thermal therapy is the application of the heat or cold to change the cutaneous, intraarticular or core temperature of the soft tissue with the intention of improving the symptoms of certain conditions $[2,13]$. The application of moist heat is a routinely prescribed therapy in today's medical field. The body's physiological response to moist heat is dilation of the blood vessels, causing an increase in the blood flow to the area under treatment. Increased local circulation enhances recovery by flushing away the waste products and bringing in fresh blood cells to the treatment area [2]. Some of the characteristics of heat therapy (thermotherapy) application that can affect effectiveness are type of therapy (such as hot packs, cold packs, and ice packs - administered with or without massage), duration of treatment application, length and schedule of treatment [4].

\section{Categories, Classifications and Methods of Applying Heat Therapy}

Heat therapy in African traditional medicine is categorized into the following three different modalities according to the temperature level and time duration:

1. Diathermia.

Diathermia involves heating up to $41^{\circ} \mathrm{C}$ with applications in physiotherapy for the treatment of rheumatic diseases as muscles and joints. Its principle is based on the use of low temperature for approximately an hour to accelerate the cell healing and increasing the blood flow and metabolic rates.

2. Hyperthermia.

The temperature of a part of the body or of the whole body can be raised to a higher-than-normal level $\left(41^{\circ} \mathrm{C}\right.$ - $45^{\circ} \mathrm{C}$ ), which may allow other types of cancer treatments (radiation therapy or chemotherapy) to work better than usual. This type of heat therapy has applications in oncology for cancer treatment. It consists of increasing the temperature of the tissue to kill the malignant cells and save the healthy tissue.

3. Thermal ablation.

Very high temperatures (above $45^{\circ} \mathrm{C}$ ) can be used to destroy cells within a localized section of a tumor. This is commonly used in oncology for cancer treatment, in urology for benign prostatic hyperplasia (BPH) treatment, and in cardiology for heart stimulations, and also in other areas. It is based on the use of a hot or a cold source to ablate the unhealthy tissue by elevating the temperature or cooling down the targeted tissue.

Classification of heat therapy has been given as follows [14]:

1. On the basis of contact of heat: a. Direct heat therapy. b. Indirect heat therapy.

2. On the basis of mode of transfer: a. Conduction. b. Convection. c. Radiation.

3. On the basis of type of heat: a. Dry heat therapy. b. Moist heat therapy.

4. On the basis of Penetration of Heat: a. Superficial heat therapy. b. Deep heat therapy.

5. On the basis of use of heat (classified in Figure 1).

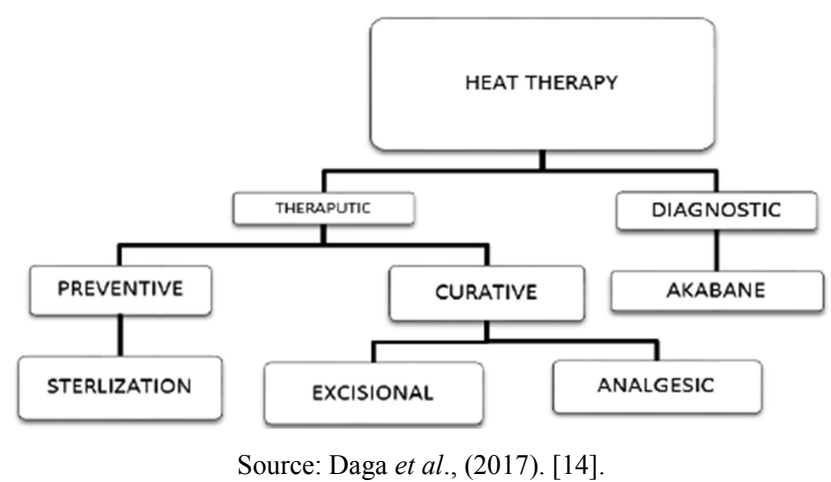

Figure 1. Diagrammatic classification of heat therapy on the basis of use of heat.

Thermal therapy comprises the implementation of any superficial heat or warmth application to the skin via conduction or convection. Superficial heat has been used for centuries to manage such pain occurring in the lower back region with specific goal of relieving pain, altering the physiologic processes underlying tissue healing, and affecting the plasticity of connective tissue, including muscle, tendon, ligament, and joint capsule [2]. Thermal therapy is believed to influence pain, to increase superficial and deep muscle tissue temperature and blood flow affecting muscle nerve conduction velocity [8]. Superficial modes of heat therapy include hot water bottles, heat pads, electric heat pads, heat wraps, heated stones, soft heated packs filled with grain, poultices, hot towels, hot baths, sauna, paraffin, steam, and infrared heat lamps [2,3]. An alternative mode of heat therapy is deep-heat therapy, which involves conversion of another form of energy to heat (e.g., shortwave diathermy, microwave diathermy, ultrasound). Common examples of superficial thermotherapy are whirlpools, hot tubs and Jacuzzis, moist hot packs, and paraffin baths.

The closer a therapeutic system is to nature, the more 
effective it is. Heat therapy in African traditional medicine therefore includes the following methods:

1. Heat from the fire place.

2. Sun Therapy.

3. Hot baths such as steam inhalation or bath, hot fomentations, whole body hot bath, hot foot bath, Seitz bath and contrast bath, etc. Hot baths are classified according to the temperature of the water used. Some of the temperatures of the various hot baths are: tepid $\left(27^{\circ} \mathrm{C}-33^{\circ} \mathrm{C}\right)$, warm $\left(33^{\circ} \mathrm{C}-37^{\circ} \mathrm{C}\right)$, hot $\left(37^{\circ} \mathrm{C}-40^{\circ} \mathrm{C}\right)$, very hot $\left(40^{\circ} \mathrm{C}\right.$ and above $)$.

Some examples of heat therapy are: sun bath, Agnikarma, Swedana, moxibustion, Tau-dam, kaii/Wasm, fire therapy, Akabane, Metsa, hot needling, Fire cupping, Banki, Hot stone, Sauna therapy, Cauterization, Hot lamp, Parafine wax, Hot bottles, fluidotherapy, herbal transdermal ionization, dip and wrap therapy, Sitz bath, diathermy, laser, maser etc. are the therapies which belongs to heat therapies in different health care systems [14].

\section{Some Herbs Used in Heat Therapy}

In African traditional medicine, heat therapy works well when combined with other treatment modalities such as exercise, appropriate diet and herbal remedies. Some herbs used in heat therapy include: Vervain (Verbena hastata), Lemon grass (Cymbopogon citratus), Siam weed (Chromolaena odorata), Neem leaves (Azadirachta indica), Sweet basil (Occimum gratissimum), Bitter leaf (Vernonia amygdalina), Mango leaves (Magnifera indica), and Pawpaw (Carica papaya). Other relevant herbs have also been listed, such as: Wheatgrass (Triticum aestivum), European mistletoe (Viscum album), Ginger (Zingiber officinale), Ephedra (Ephedra campylopoda), and Oriental mistletoe (Viscum cruciatum) [15].

\section{Simple Procedures and Durations for Heat Therapy in African Traditional Medicine}

Explanations on some simple procedures for heat therapy in African traditional medicine are given below:

\subsection{Steam Inhalation}

Steam inhalation involves the inhalation of steam with or without some herbs in the treatment of some diseases. Conditions for this are mainly respiratory diseases such as cold, cough, sinusitis, pneumonia, bronchitis and sometimes feverish conditions etc. Requirements include: plastic bowl or cup, water at its boiling point, towel or any thick cloth.

Procedure:

Fill tea kettle with boiling water; add medication to the water. Carry to bedside and place on hot plate. Cover spout with a cone made of rolled paper material in order to carry steam directly to person's nose and mouth. Alternatively, boil water and pour into a bowl. Drape towel over the back of the head. Turn on a timer (if necessary). Shut the eyes and slowly lower the head toward the hot water to about 8-12 inches away from the water. Avoid contact with hot water. Inhale slowly and deeply through the nose for at least $2-5$ minutes.

\subsection{Hot Fomentations}

This is a local application of moist heat to relieve colds, nerve pains, sprains, muscle spasm etc. in the treatment of some diseases, joint and nerve pains, fractures, cold, pneumonia, arthritis, muscle spasms, sprains and strains. This is most commonly practiced in heat therapy. Requirements include: clean towel or piece of cloth, basin and hot water (appropriate temperature). In Africa, hot water compress is applied on the abdomen and waist of women up to 6 weeks after birth. This is done to facilitate the contraction of the uterus and the abdominal muscles back to normal size and shape, and usually in combination with the puerperal pepper soup prepared with African fertility enhancing herbs. It is applicable to all ages including new born baby.

Procedure:

Simple application of hot wet towel on the area to be treated.

\subsection{Hot Foot Bath}

This is a simple but old-fashioned treatment. The process is putting the feet in hot water for a time. The hotter the water the more the patient will perspire. The benefits include: (1). warming the patient all over and improve blood circulation. (2). Serves as a good relaxer; warm feet enhance sleep. (3). It relieves congestions in the feet, head and other organs as blood is drawn more to the feet. (4). Eases the symptoms of common cold. (5). Relieves pelvic cramps, abdominal pains, prostate problems and menstrual pains.

Procedure:

In an open and airy room, place both feet in the hot water, the temperature not exceed $43{ }^{\circ} \mathrm{C}$. The container must be wide enough so that both feet can be placed side by side on the bottom of the container. The water must be well above the ankles but slightly below the knees. Add hot water gradually and with care. Keep a cold compress on the head and neck. After 15-30 minutes, the feet should be cooled off with cold water and dried properly ensuring that the webs of the toes are dried. If sweating continues after the bath, apply a cold shower.

\subsection{Seitz Bath (Hip Bath and Half-bath)}

Seitz baths act as analgesic and to increase blood flow. It is usually applied in treating the following ailments: (1). Prostate diseases. (2). Hemorrhoids, piles and fissures. (3). Genital and urinary tract diseases and disorders. (4). Urinary retention. (5). Cystitis (bladder, etc). (6). After hemorrhoidectomy. (7). Chronic constipation. (8). Diarrhea. (9). Congestion in the abdomen or pelvic region. (10). Sinusitis. (11). Pelvic inflammatory diseases. (12). Uterine disease e.g. painful menstruation. Two washtubs or wash 
basins of different sizes are usually required.

Procedure:

The feet are put into small basin containing hot water of which the temperature should not exceed $41^{\circ} \mathrm{C}$ or $43^{\circ} \mathrm{C}$. In this position, cover the patient with blanket or towel if sweating is desired. Apply cold compresses to the forehead when sweating starts. The duration of this bath is $10-15$ minutes for a regular tonic effect and $20-40$ minutes for treatment purposes. Place an elevator of above 3-4 inches under the bigger basin. Place towels on the edges to protect the hands and the back from burning. Usually a tub made for Seitz bath has an inbuilt elevator on one side of it. Fill the basins with hot infusion of the appropriate herbs. The water level should reach to the middle of the abdomen. The temperature should be between $34^{\circ} \mathrm{C}-37^{\circ} \mathrm{C}$, but must be suitable for the patient. The procedure is ended by cooling the water to $18^{\circ} \mathrm{C}-21^{\circ} \mathrm{C}$. Dry the patient and encourage rest for about 40 minutes.

\subsection{Hot and Cold Contrast Bath}

This is the application of alternate hot and cold water to affected areas. The alternate application of hot and cold water dilates and contrasts the blood vessels bringing a supply of fresh blood to the area being treated. This enhances healing. Requirements include: hot and cold water, bowls, and towels.

Procedure:

Start with hot water of about $105^{\circ} \mathrm{F}$ for 3 minutes. Apply cold water or ice water for 30 seconds. Add hotter water to the first basin to increase the temperature. The procedure can be repeated up to eight times. On the whole duration of the bath will be 30 minutes. Keep adding hot or cold/ice water respectively to the two basins till the end of the procedure. Always start with hot water and end with cold. Always treat a larger area than injured.

\subsection{Sun Therapy}

Sun therapy is also called heliotherapy. Without sunlight there will be no life. The energy released by sun light (solar energy) affects man in various ways. Sun rays have therapeutic powers that are beneficial to man's health. Growth and development of the body is dependent upon energy from sunlight. The benefits of sun therapy are:

1. It is a source of energy. This energy is free, abundant and is readily available.

2. Sunlight converts the inactive vitamin $\mathrm{D}$ in the body to its active form which is essential for the development of a healthy bone.

3. Solarized water, sugar, oil etc are effective in the treatment of many ailments.

4. Sunlight is also a good source of skin pigmentation. Sunlight has been found to be a potential treatment for pandemic coronavirus infections [16].

Procedure:

First cover the head with a wet towel. Either lie down or sit in the sun for a while. Once sweating starts, move away from the sun and bathe with cold water.
Generally, a variation in duration of heat therapy has been reported [4]. The desired effect in heat therapy is for the heat to penetrate deep into the muscles. Therefore, in many cases, the longer the heat is applied the better. However, the duration of the therapy is based on some factors such as type or magnitude of the injury and the type of heat therapy applied on the affected body part. Generally, for minor tensions and pains, short duration of heat therapy may be sufficient (e.g. 15 - 20 minutes). For more intense pains and injuries, longer sessions may be more beneficial (30 minutes, 2 hours or more).

\section{General Benefits of Heat Therapy in African Traditional Medicine}

The general benefits of heat therapy in African traditional medicine are very prevalent. Heat therapy decreases the number of invading organisms. Heat therapy also dilates the blood vessel of the muscles. This process increases the flow of oxygen and nutrients to the muscles and soft tissues. Helps relieve pains in the lower back and other parts of the body. Heat stimulates the sensory receptors in the skin. Heat application facilitates stretching of the soft tissues around the spine, etc. Nowadays, thermal therapy has considerably improved. It has been used in many medical applications and many techniques have been developed [13]. Heat therapy has been used extensively for treating several diseases such as: sickle cell disease [17], primary dysmenorrhea [18], skeletomuscular pain, trauma, inflammatory and degenerative rheumatic diseases [19], and osteoarthritis [4]. Others include: acute and non-specific chronic low back pain $[2,8,20]$, fibromyalgia [7], cutaneous leishmaniasis [21, 22], tumours [13], musculoskeletal injuries [5, 23], Alzheimer's and Parkinson's diseases [24], diabetic kidney disease [25], etc. Therapeutic effects of heat include: increased muscle flexibility of the lower back [26], increasing the extensibility of collagen tissues, decreasing joint stiffness reducing pain, relieving muscle spasm, reducing inflammation and edema aids in the post-acute phase of healing, and increasing blood circulation. Increase circulation to affected area provides nutrients and oxygen for better healing [15].

\section{Contra-indications and Safety Precautions in Heat Therapy}

The following contra-indications and safety precautions should be observed in heat therapy:

1. Heat therapy should not be applied on swollen bruised parts of the body.

2. Heat therapy is not suitable for hypertensive and diabetic patients, and patients suffering from anemia, dermatitis, deep vein thrombosis, calcification of the arteries, severe cognitive impairment, seizure disorders e.g. epilepsy and peripheral vascular diseases.

3. Heat therapy should not be applied in open wounds, and should not be applied during pregnancy; heat therapy should 
not be applied to infants.

4. Thermotherapy should be used with caution in patients with diabetes mellitus, multiple sclerosis, poor circulation, spinal cord injuries, and rheumatoid arthritis because it may cause disease progression, burns, skin ulceration, and increased inflammation [2]. As a guide, the effect of temperature on biological tissues is shown in Table 1 [12].

Table 1. The effect of temperature on biological tissues.

\begin{tabular}{llll}
\hline $\begin{array}{l}\text { Temperature } \\
\text { Range }\left({ }^{\circ} \mathbf{C}\right)\end{array}$ & $\begin{array}{l}\text { Time } \\
\text { Requirements }\end{array}$ & Physical Effects & Biological Effects \\
\hline$<-60$ & $>10$ min & Freezing & $\begin{array}{l}\text { Complete cellular destruction } \\
\text { Decreased blood perfusion, decreased cellular metabolism, } \\
\text { hypothermic killing }\end{array}$ \\
$0-25$ & & Decreased permeability & Growth \\
$30-39$ & No time limit & No change & Changes in the optical properties of tissue \\
$40-46$ & $30-60$ min & Necrosis, coagulation & Increased perfusion, thermoto-lerance induction, hypothermic killing \\
$47-50$ & $>10$ min & Necrosis, coagulation & Protein denaturation, not subtle effects \\
$>50$ & After $\sim 2$ min & Coagulation, ablation & Cell death \\
$60-140$ & Seconds & Vaporization & Cell shrinkage and extracellular steam vacuole \\
$100-300$ & Seconds & Carbonization, smoke generation & Carbonization \\
$>300$ & Fraction of a & second &
\end{tabular}

Source: Habash et al., (2006). [12].

The characteristics of hot and cold treatment modalities and safety precautions are shown in Table 2 [5].

Table 2. Characteristics of hot and cold treatment modalities and precautions.

\begin{tabular}{|c|c|c|c|c|}
\hline & Method of Application & Indications & Precautions & Adverse Treatment Effects \\
\hline Cryotherapy & $\begin{array}{l}\text { Ice pack } \\
\text { Vapo-coolant spray } \\
\text { Ice massage } \\
\text { Cold whirlpool }\end{array}$ & $\begin{array}{l}\text { Acute injury/trauma } \\
\text { Chronic pain } \\
\text { Muscle spasm } \\
\text { Delayed onset muscle } \\
\text { soreness } \\
\text { Inflammation }\end{array}$ & $\begin{array}{l}\text { Circulatory insufficiency } \\
\text { Cold allergy } \\
\text { Advanced diabetes }\end{array}$ & $\begin{array}{l}\text { Cardiovascular effects (bradycardia) } \\
\text { Raynaud's phenomenon } \\
\text { Cold urticaria } \\
\text { Nerve and tissue damage } \\
\text { Slowed wound healing } \\
\text { Frostbite }\end{array}$ \\
\hline Thermotherapy & $\begin{array}{l}\text { Conduction } \\
\text { Hydrocollator pack } \\
\text { Low-level heat wrap } \\
\text { Paraffin bath }\end{array}$ & $\begin{array}{l}\text { Acute muscular pain } \\
\text { Delayed onset muscle } \\
\text { soreness } \\
\text { Menstrual pain }\end{array}$ & $\begin{array}{l}\text { Diabetes mellitus } \\
\text { Multiple sclerosis } \\
\text { Peripheral vascular disease } \\
\text { Spinal cord injuries } \\
\text { Rheumatoid disease }\end{array}$ & Burns \\
\hline $\begin{array}{l}\text { Thermotherapy } \\
\text { (continued) }\end{array}$ & $\begin{array}{l}\text { Convection } \\
\text { Fluidotherapy } \\
\text { Hydrotherapy }\end{array}$ & $\begin{array}{l}\text { Tendonitis } \\
\text { Joint contractures } \\
\text { Muscle spasms } \\
\text { Osteoarthritis }\end{array}$ & $\begin{array}{l}\text { Pregnancy } \\
\text { Laminectomy sites } \\
\text { Spinal cord } \\
\text { Malignancy } \\
\text { Vascular insufficiency } \\
\text { Eye, testes, heart } \\
\text { Growth plates } \\
\text { Anesthetic area } \\
\text { Joint prosthesis } \\
\text { Total hip replacement }\end{array}$ & $\begin{array}{l}\text { Burns } \\
\text { Increased pain } \\
\text { Increased inflammation }\end{array}$ \\
\hline $\begin{array}{l}\text { Contrast } \\
\text { Therapy }\end{array}$ & $\begin{array}{l}\text { Alternating cryotherapy } \\
\text { and thermotherapy }\end{array}$ & $\begin{array}{l}\text { Complex reflex } \\
\text { sympathetic dystrophy } \\
\text { Desensitization of skin }\end{array}$ & & $\begin{array}{l}\text { Burns } \\
\text { Frostbite } \\
\text { Cold urticaria } \\
\text { Raynaud's phenomenon }\end{array}$ \\
\hline
\end{tabular}

Source: Nadler et al., (2004). [5].

\section{Conclusion}

Heat therapy has been proven as a cheap, simple, effective and beneficial procedure in African traditional medicine. It is applicable to any individual irrespective of age, race or religion. Some beneficial herbs used in heat therapy in African traditional medicine were highlighted in this paper. Several categories, examples, procedures, durations, benefits, contra-indications and safety precautions of heat therapy were also highlighted.

\section{Recommendations}

As an aspect of African traditional medicine, imbibing heat therapy in traditional healthcare delivery systems is highly recommended. Although it is simple and beneficial, the 
practice must be applied within a specific time and appropriate temperature range to avoid its adverse effects. Further research and development works in this area are also recommended in order to promote heat therapy and its benefits in Nigeria and Africa in general.

\section{References}

[1] Bleakley CM, Costello JT. (2013). Do thermal agents affect range of movement and mechanical properties in soft tissues? A systematic review. Archives of Physical Medicine and Rehabilitation. 94: 149-163.

[2] Ajibola OOE, Fagbolagun KO, Folorunso OP. (2018). Design and fabrication of a moist heat therapy device for treating nonspecific low back pain. The West Indian Journal of Engineering. 41 (1): 55-64.

[3] Mallanga GA, Yan N, Stark J. (2014). Mechanisms and efficacy of heat and cold therapies for musculoskeletal injury. Postgrad Med. 1-9.

[4] Brousseau L, Yonge KA, Robinson V, Marchand S, Judd M, Wells G, Tugwell. P. (2003). Thermotherapy for treatment of osteoarthritis. Cochrane Database of Systematic Reviews. Issue 4. Art. No.: CD004522. DOI: 10.1002/14651858.CD004522.

[5] Nadler SF, Weingand K, Kruse RJ. (2004). The physiologic basis and clinical applications of cryotherapy and thermotherapy for the pain practitioner. Pain Physician. 7 (3): 395-399.

[6] Habash R, Habash M, El-Hage M. (2017). Therapeutic heat and cold in cardiac rehabilitation. Physical Therapy and Rehabilitation. 4 (11): 1-12.

[7] Yuan SLK (2013). Electrotherapy, thermotherapy and phototherapy modalities in fibromyalgia: A critical review of the literature. OA Musculoskeletal Medicine. 1 (2): 1-8.

[8] Wittenwiler S, Stoop R, Hohenauer E, Clijsen R. (2018). Thermal therapy in patients suffering from non-Specific chronic low back pain -a systematic review. International Journal of Clinical Medicine. 9: 294-314.

[9] Ekeopara CA, Ugoha, AMI. (2017). The contributions of African traditional medicine to Nigeria's health care delivery system. IOSR Journal of Humanities and Social Science. 22 (5): $32-43$.

[10] Sanadhya YK, Sudhanshu S, Jain SR, Sharma N. (2013). Naturopathy system - a complimentary and alternative aid in dentistry - a review. Journal of Evolution of Medical and Dental Sciences. 2 (37): 7077-7083.

[11] Akpomuvie OB. (2014). The perception of illness in traditional Africa and the development of traditional medical practice. International Journal of Nursing. 1 (1): 51-59.

[12] Habash RWY, Bansal R, Krewski D, Alhafid HT. (2006). Thermal therapy, part 1: an introduction to thermal therapy. Critical Reviews in Biomedical Engineering. 34 (6): 459-489.
[13] Mellal I, Oukaira A, Kengene E, Lakhssassi A. (2017). Thermal therapy modalities for cancer treatment: a review and future perspectives. International Journal of Applied Science Research and Review. 4 (2: 4): 1-11.

[14] Daga H, Raval S, Toshikhane H, Jethava N. (2017). Materials and methods of different heat therapy. World Journal of Pharmaceutical Research. 6 (5): 1602-1614.

[15] Ben-Arye E, Lavie O, Samuels N, Khamaisie H, Schiff E, Raz OG, Mahajna J. (2017). Safety of herbal medicine use during chemotherapy in patients with ovarian cancer: a "bedside-tobench" approach. Med Oncol. 34 (54): 1-6.

[16] Enwemeka CS, Bumah VV, Masson-Meyers DS. (2020). Light as a potential treatment for pandemic coronavirus infections: a perspective. Journal of Photochemistry and Photobiology, B: Biology. 207 (111891): 1-7.

[17] Adewoyin AS. (2014). Management of sickle cell disease: a review for physician education in Nigeria (Sub-Saharan Africa). Anemia, vol. 2015, Article ID 791498. https://doi.org/10.1155/2015/791498.

[18] Igwea SE, Tabansi-Ochuogu CS, Abaraogu UO. (2016). TENS and heat therapy for pain relief and quality of life improvement in individuals with primary dysmenorrhea: A systematic review.

[19] Jeziorski K. (2018). Hyperthermia in rheumatic diseases: a promising approach? Reumatologia. 56 (5): 316-320.

[20] Dehghan M, Farahbod F. (2014). The efficacy of thermotherapy and cryotherapy on pain relief in patients with acute low back pain, a clinical trial study. Journal of Clinical and Diagnostic Research. 8 (9): 1-4.

[21] Cardona-Arias JA, Vélez, ID, López-Carvajal L. (2015). Efficacy of thermotherapy to treat cutaneous leishmaniasis: a meta-analysis of controlled clinical trials. PLoS ONE. 10 (5): $1-15$.

[22] Sharquie KE, Al-Mashhadani SA, Noaimi AA, Al-Zoubaidi, WB. (2015). Microwave thermotherapy: New treatment for cutaneous leishmaniasis. Our Dermatol Online. 6 (2): 125-129.

[23] Kim K, Monroe JC, Gavin TP, Roseguini BT. (2020). Skeletal muscle adaptations to heat therapy. Journal of Applied Physiology. 128 (6): 1635-1642.

[24] Hunt AP, Minett GM, Gibson OR, Kerr GK, Stewart IB. (2020). Could heat therapy be an effective treatment for Alzheimer's and Parkinson's diseases? Review. 10 (1556): 114.

[25] Guo J, Gao Y, Wang Y, Liu WJ, Zhou J, Wang Z. (2019). Application of herbal medicines with heat-clearing property to anti-microinflammation in the treatment of diabetic kidney disease. Evidence-Based Complementary and Alternative Medicine. Article ID 6174350. 1-6.

[26] Fuentes-Leon P, Jara-Poblete N, Bastias-Sanchez P, Vitzel KF, Marzuca-Nassr GN. (2016). Heat transfer by three types of hot pack and its implication on the flexibility of the lower back: a randomized, controlled trial. Fisioter Pesqui. 23 (2): 201-209. 